\title{
STRATEGI KOMUNIKASI PROGRAM TANAM JAJAR LEGOWO KEPADA MASYARAKAT PETANI PADI
}

\author{
Nuzuwir J oni ${ }^{1 *}$, Asmawi ${ }^{2}$, Ernita Arief ${ }^{3}$ \\ ${ }^{1}$ Graduate Student of Communication Science, Universitas Andalas, Padang, Indonesia \\ ${ }^{2}$ Department of Communication Science, Universitas Andalas, Padang, Indonesia \\ ${ }^{3}$ Department of Communication Science, Universitas Andalas, Padang, Indonesia
}

\begin{tabular}{|c|}
\hline ARTICLE INFORMATION \\
\hline $\begin{array}{l}\text { Submitted : } 18 \text { August } 2018 \\
\text { Review : } 05 \text { April } 2019 \\
\text { Accepted : } 10 \text { May } 2019\end{array}$ \\
\hline Available online: June 2019 \\
\hline KEYWORDS \\
\hline $\begin{array}{l}\text { Communication strategy; Legowo row planting } \\
\text { program and farming community }\end{array}$ \\
\hline CORRESPONDENCE \\
\hline
\end{tabular}

*E-mail: jnuzuwir@yahoo.co.id

\section{A. PENDAHULUAN}

K omoditi padi memiliki peranan sangat penting yakni sebagai salah satu dari kebutuhan pangan pokok sebagian besar masyarakat Indonesia. Kebutuhan akan padi/ beras tersebut setiap tahun selalu meningkat seiring dengan laju pertambahan penduduk, peningkatan pendapatan, disamping untuk memenuhi kebutuhan industri olahan. Laju peningkatan kebutuhan padi/beras dimaksud lebih tinggi dibandingkan dengan peningkatan produksi padi setiap tahun sehingga dikhawatirkan akan terjadi rawan pangan/krisis pangan beberapa tahun ke depan. Untuk mengantisipasi hal tersebut, pemerintah harus memiliki ketahanan pangan yang kuat. Menurut Kataren, dkk. (2018) bahwa ketahanan pangan dalam implementasinya berkaitan dengan tiga (3) aspek penting yang saling terkait satu sama lain: 1) produksi dan ketersediaan pangan (food availability); 2) keterjangkauan pangan (food accessibility); dan 3) keterjaminan/ kepastian

\section{A B S T R A C T}

System of Legowo row planting technology is innovation in agriculture which is highly recommended by the government in an effort to increase rice production in Indonesia. To accelerate the adoption of these technologies, it is necessary to prepare the right communication strategy. This study aims to determine the communication strategy of the Jajar Legowo planting program to the rice farming community in Padang City. This type of research is qualitative. Research data is obtained through indepth interviews, participatory observation, and documentation. The data is processed by Miles and Huberman's interactive analysis model and the validity of the data by triangulation. The results showed that the communication strategy of legowo planting program was: (1) getting to know the target audience, namely rice farmers; (2) compile messages, in the form of benefits and procedures for implementing the program; (3) establish methods, in the form of: persuasion, educative, informative, and redundancy methods, (4) media use, in the form of discussions, lectures, brochures, leaflets, and banners. In addition, people's habits such as gathering and sitting in the store can be used as a place to introduce new technology.

mendapatkan pangan (food stability) sesuai mutu dan keamanan pangan.

Dalam hal ini, pemerintah melalui Kementerian Pertanian telah menjabarkan kebijakan pembangunan pertanian dalam program "Swasembada Pangan Padi, Jagung dan Kedelei". Untuk mewujudkan program tersebut, pemerintah mengeluarkan Permentan No. 03/Permentan/OT.140/2 /2015 tentang Pedoman Upaya Khusus (UPSUS) peningkatan produksi padi, jagung dan kedelai melalui program perbaikan jaringan irigasi dan sarana pendukungnya tahun 2015.

Salah satu program pendukung program UPSUS tersebut adalah pelaksanaan program Gerakan Penerapan Pengelolaan Tanaman Terpadu (GP-PTT). Menurut Zaini (2015 : 1) Pengelolaan Tanaman Terpadu adalah suatu pendekatan inovatif dan dinamis dalam upaya meningkatkan produksi dan pendapatan petani melalui perakitan komponen teknologi secara partisipatif bersama petani. Melalui Pengelolaan Tanaman Terpadu (PTT Padi Sawah) telah 
diperkenalkan berbagai teknologi budidaya padi, antara lain sistem tanam Jajar Legowo (Legowo). Firdaus (2015) mengatakan bahwa pengenalan dan penggunaan sistem tanam tersebut disamping untuk mendapatkan pertumbuhan tanaman yang optimal juga ditujukan untuk meningkatkan hasil dan pendapatan petani. Fatchiya, dkk (2016) menemukan bahwa Penerapan teknologi ini berkorelasi positif dengan kondisi ketahanan pangan rumah tangga petani, yaitu petani yang menerapkan inovasi teknologi lebih intensif memiliki tingkat ketahanan pangan yang lebih baik.

Teknologi sistem tanam jajar legowo padi merupakan teknologi yang sudah teruji dan melalui proses pengkajian secara mendalam oleh Balai Pengkajian Teknologi Pertanian (BPTP) pertanian. Teknologi ini secara nyata dapat meningkatkan produksi dan produktivitas tanaman padi. Oleh karena itu, menurut Hidayat dkk.,(2017) perlu dilakukan penerapan strategi yang berbasis pada hubungan yang terjalin baik dengan publik sasaran. Dalam hal ini, publik sasarannya adalah para petani tanaman padi. Pemerintah sangat berharap sekali kepada para petani untuk mengadopsi teknologi sistem tanam tersebut. Akan tetapi, tidak mudah bagi pemerintah untuk meyakinkan para petani tentang sesuatu hal yang baru bagi mereka. Pada hal, menurut penelitian Farid, dkk. (2018) sikap petani memiliki kecenderungan positif sebanyak $72,5 \%$ terhadap peluang adopsi sistem tanam jajar legowo berdasarkan prinsip sistem tanam jajar legowo. Untuk itu, pemerintah perlu mempersiapkan suatu strategi komunikasi yang tepat sasaran dalam merubah sikap petani agar dapat mengadopsi teknologi sistem tanam jajar legowo di lahan mereka.

Strategi komunikasi yang tepat sasaran tersebut perlu dipersiapkan dengan cermat. Menurut Azizah (2010), hal ini dilakukan karena berhubungan dengan karakteristik masyarakat petani, sumber daya (manusia maupun alam), tipologi masyarakat, struktur masyarakat dan kelembagaan desa yang berbeda-beda di setiap wilayah. Perencanaan yang detil juga diperlukan mengingat program penerapan teknologi sistem tanam jajar legowo ini harus disesuaikan dengan kebutuhan, keinginan dan kemampuan masyarakat petani. Apabila penyampaian inovasi ini tidak dibingkai dalam strategi komunikasi yang tepat maka program yang bermanfaat dan menghabiskan banyak dana akan sia-sia. Banyak program yang terlihat bermanfaat terbukti tidak dapat diterima sasaran (masyarakat) karena menggunakan strategi komunikasi yang tidak dirancang secara matang.
Penelitian ini penting dilakukan karena dengan mengkaji strategi komunikasi maka akan mudah mengetahui kelemahan dan kekuatan komunikasi yang dilakukan oleh penyuluh pertanian. Menurut Indardi (2016), aspek komunikasi dipercaya sebagai salah satu faktor penting untuk mencapai keberhasilan pembangunan, khususnya dalam pemberdayaan masyarakat. Kemudian, dengan adanya strategi komunikasi yang optimal, maka tujuan yang diharapkan dari program ini akan tercapai secara optimal. Pada akhirnya pemerintah akan dapat lebih fokus pada satu atau dua media komunikasi saja sehingga dapat meminimalkan biaya yang dikeluarkan pemerintah. Zulkarnain dkk (2017) menyatakan bahwa strategi komunikasi dapat berperan untuk mengubah pandangan masyarakat yang tadinya negatif menjadi positif terhadap teknologi. Menurut Umniyati, dkk. (2017) pengetahuan menjadi faktor penting dalam perubahan sikap masyarakat, karena "proses perubahan sikap khalayak dimulai ketika informasi menyentuh kesadaran, pemahaman dan pengetahuan mereka.

Dari uraian diatas maka tujuan yang hendak dicapai dalam penelitian ini adalah untuk mengetahui dan menggambarkan strategi komunikasi program tanam jajar legowo kepada masyarakat petani tanaman padi di Kota Padang. Unit analisis yang digunakan untuk menjelaskan strategi komunikasi yang digunakan penyuluh pertanian Koto Tangah Kota Padang adalah konsep strategi yang dikemukakan oleh Anwar Arifin dalam bukunya yang berjudul "Strategi Komunikasi: Sebuah Pengantar Ringkas" bahwa untuk mencapai tujuan komunikasi yang efektif maka strategi komunikasi yang dilakukan adalah mengenal khalayak, menyusun pesan, menetapkan metode dan seleksi dan penggunaan media.

\section{B. METODE PENELITIAN}

$\mathrm{P}$ enelitian ini mengambil lokasi di kecamatan Koto Tangah Kota Padang, dengan mengambil penyuluh pertanian Balai Penyuluhan Pertanian (BPP) Koto Tangah. Penelitian ini menggunakan jenis penelitian kualitatif, dengan sifat deskriptif yang berusaha mendeskripsikan dan menjelaskan objek penelitian yang bersifat faktual secara sistematis dan akurat.

Data penelitian dikumpulkan dengan cara wawancara mendalam, observasi partisipasi, dan dokumentasi. Pengumpulan data penelitian kualitatif menurut Sugiyono (2016:225) dapat dilakukan pada natural setting (kondisi yang alamiah), sumber data primer dan teknik 
pengumpulan datanya lebih banyak pada observasi berperan serta (partisipan observation), wawancara mendalam (indepth interview), dan dokumentasi. Informan penelitin ditetapkan dengan metode purposive sampling. Purposive sampling adalah teknik pengambilan sampel sumber data dengan pertimbangan tertentu (Sugiyono 2016:218). Pertimbangan tertentu ini, maksudnya adalah orang yang dianggap lebih mengetahui dan memiliki banyak informasi tentang objek penelitian, yakni tentang strategi dan pelaksanaan komunikasi penyuluh pertanian dalam mengkomunikasikan teknologi sistem tanam jajar legowo kepada petani padi di Koto Tangah. Dalam hal ini, Peneliti melakukan wawancara terhadap beberapa key informan adalah koordinator Penyuluh Pertanian sekaligus sebagai kepala Balai Penyuluhan Pertanian, dan (b) Informan pendukung, diantaranya adalah programer penyuluh pertanian, dan penyuluh pertanian lapangan.

Data diolah dan dianalisa dengan menggunakan teknik analisis interaktif, yang dikemukakan oleh Miles dan Hubberman, yakni reduksi data, display data dan penarikan kesimpulan dan verfikasi data. Data yang terkumpul dilakukan reduksi data, yakni proses pemilihan, pemusatan perhatian pada penyederhanaan, pengabstrakan dan transformasi data kasar yang muncul dari catatan-catatan ketika melakukan penelitian di lapangan. Selanjutnya penyajian data yang dilakukan dengan cara mengumpulkan informasi dalam bentuk teks naratif atau grafik jaringan yang bertujuan mempertajam pemahaman penelitian terhadap informasi yang dipilih. Terakhir adalah penarikan kesimpulan atau verifikasi terhadap data penelitian yang telah di sajikan dalam bentuk yang lebih sederhana Kesimpulan akhir tidak akan terjadi sampai proses pengumpulan data berakhir.

Untuk keabsahan data, peneliti menggunakan teknik triangulasi. Menurut Moleong (2016:332) analisa triangulasi adalah cara terbaik untuk menghilangkan perbedaan-perbedaan konstruksi kenyataan yang ada dalam konteks suatu studi sewaktu mengumpulkan data tentang berbagai kejadian dan hubungan dari berbagai pandangan. Triangulasi yang digunakan, yaitu triangulasi sumber (mengecek sumber informasi dari hasil wawancara antara key informan dan informan pendukung), serta triangulasi teknik (mengecek hasil wawancara mendalam yang diperoleh dari informan, lalu hasilnya akan dicek dengan data observasi partisipan dan dokumentasi).

\section{HASIL DAN PEMBAHASAN}

$\mathrm{S}$ trategi komunikasi akan berjalan lancar apabila didukung oleh perencanaan yang matang, karena hal ini akan menjadi kunci bagi keberhasilan sebuah program pemerintah. Untuk itu, penyuluh pertanian Kota Padang juga menentukan perencanaan terlebih dahulu sebelum mengenalkan suatu inovasi teknologi kepada sasaranya. Salah satu langkah perencanaan yang dilakukan oleh penyuluh pertanian Kota Padang dalam menjalankan strategi komunikasinya adalah menentukan khalayak yang menjadi sasaran program.

Mengenal khalayak berarti melakukan proses identifikasi terhadap khalayak yang akan dijadikan sasaran kegiatan, terutama khalayak yang secara tidak langsung dapat mempengaruhi keberlangsungan suatu program di lapangan. Penentuan khalayak perlu dilakukan, karena penyuluh pertanian Kota Padang membutuhkan sasaran sebagai tempat pelaksanaan program pemerintah dan juga agar kegiatan komunikasi yang dilakukan bisa terarah. Mengenal khalayak adalah langkah pertama bagi komunikator dalam usaha komunikasi yang efektif. Mengenal dan memahami karakteristik khalayak, berarti suatu peluang untuk mencapai keberhasilan komunikasi. Dalam menentukan khalayak sasaran program, penyuluh pertanian Kota Padang menetapkan petani tanaman padi sebagai khalayak sasaran dari program pemerintah.

Berdasarkan temuan di lapangan bahwa pada masyarakat petani padi di kecamatan Koto Tangah terdapat dua bagian yakni petani pemilik dan petani penggarap. Petani pemilik adalah petani yang memiliki lahan tani sedangkan petani penggarap disebut juga dengan buruh tani atau orang yang menerima upah atas jasanya mengelola lahan petani pemilik lahan. Dalam kenyataanya menurut Fitriani (2013), pemerintah daerah hanya memfokuskan difusi inovasi dan diseminasi teknologi kepada petani pemilik lahan saja, padahal di lapangan tidak semua petani pemilik menjadi petani penggarap. Umumnya petani pemilik juga berprofesi sebagai PNS, pedagang dan penguasa yang tidak secara langsung terlibat dalam hal menerapkan teknologi jajar legowo di lahan mereka. Jadi dalam menetapkan khalayak sasaran komunikasi program, perlu mempertimbangkan untuk mengikutkan petani penggarap sebagai sasaran kegiatan, karena petani penggaraplah yang akan menerapkan teknologi tersebut di lahan petanian tanamn padi.

Dari paparan diatas, penyuluh pertanian Kota Padang sebagai komunikator telah menjalankan langkah awal dari rumusan strategi komunikasi sebagaimana yang dikomunikasikan 
oleh Anwar Arifin (1984) dalam bukunya yang berjudul "Strategi Komunikasi: Sebuah Pengantar Ringkas" bahwa untuk mencapai tujuan komunikasi yang efektif maka strategi komunikasi yang dilakukan adalah mengenal khalayak, menyusun pesan, menetapkan metode dan seleksi dan penggunaan media.

Dalam mengenal dan menetapkan khalayak sasaran kegiatan, penyuluh pertanian Kota Padang terlebih dahulu melakukan pemetaan kharakteristik terhadap sasaran program. Untuk pemetaan kharakterisyik tersebut penyuluh pertanian Kota Padang menggunakan salah satu cara pemetaan karakteristik khalayak yang dikemukakan oleh Cangara yaitu melalui aspek sosiodemografik. Penyuluh pertanian juga mengacu kepada kelompok-kelompok yang ada dalam masyarakat yang menentukan besarnya pengaruh suatu program.

Menurut Cangara (2014:136) aspek sosiodemografik, mencakup usia, jenis kelamin, pekerjaan, pendidikan, tingkat pendapatan, agama, ideologi, etnis, termasuk pemilikan media. Dalam memetakan karakteristik khalayak yang menjadi sasaran komunikasi kegiatan, penyuluh pertanian Kota Padang melihatnya dari sisi pekerjaan dan tingkat pendapatan. Petani tanaman padi ditetapkan karena memiliki pekerjaan sebagai orang yang memiliki lahan pertanian dan mengusahakan lahannya dengan bercocok tanaman padi. Dari segi tingkat pendapatan, umumnya petani memiliki pendapatan yang rata-tara rendah sehingga membutuhkan tambahan pendapatan untuk mencukupi kebutuhan hidup mereka, yakni dengan memberikan program inovasi teknologi yang menguntungkan bagi mereka. Kemudian khalayak ditetapkan oleh penyuluh pertanian mengacu kepada salah satu kelompok yang berpengaruh terhadap pelaksanakan program yang dikemukakan oleh Cangara (2014:137), yakni sebagai kelompok pendukung. Petani ditetapkan karena sebagai kelompok yang akan menerima penerapan teknologi sistem tanam jajar legowo padi dan kelompok yang setuju pada program yang akan dilaksanakan.

Program penerapan teknologi sistem tanam jajar legowo padi adalah program pemerintah pusat yang ditujukan untuk meningkatkan produksi padi dan pendapatan petani. Sasaran utama dari pelaksanaan program ini adalah seluruh masyarakat petani tanaman padi. Sasaran program tersebut sekaligus menjadi sasaran khalayak yang menjadi target penerima pesan.

Setelah mengenal khalayak dan situasinya, merujuk kepada konsep strategi yang dikemu- kakan oleh Anwar Arifin (1984), maka langkah selanjutnya yang dilakukan oleh penyuluh pertanian Kota padang dalam perumusan strategi komunikasi adalah menyusun pesan. Sebelum pesan disampaikan, penyuluh pertanian Koto Tangah terlebih dahulu menyusun dan merancang isi atau materi pesan yang akan disampaikan kepada masing-masing khalayak sasaran. Pesan ini disusun dan dirancang pada saat mengadakan pertemuan koordinasi bersama koordinator penyuluh pertanian dan penyuluh lapangan di Kantor Balai Penyuluhan Pertanian Koto Tangah Kota Padang. Dalam menyusun pesan komunikasi tersebut, penyuluh pertanian berpedoman kepada khalayak yang menjadi target dalam pelaksanaan kegiatan. Berbeda khalayak sasaran, maka berbeda pula rancangan pesannya, karena pendekatan yang dilakukan berbeda. Kemudian, juga disusun berdasarkan kepada kebutuhan, keinginan, sikap, tingkah laku dan pengetahuan khalayak serta sosial budaya, dan tingkat pemahaman masing-masing khalayak sasaran. Menurut Susanti (2015) penyajian pesan yang tersusun akan lebih efektif daripada penyajian pesan yang tidak tersusun. Pesan akan dapat menghasilkan respon tertentu kalau dirancang dengan baik.

Secara umum pesan yang disampaikan oleh penyuluh pertanian Koto Tangah adalah berhubungan dengan besarnya manfaat program yang diperoleh, diantaranya adalah dapat meningkatkan produktifitas tanam padi, kemudahan dalam pemupukan dan penyemprotan pestisida. Pada barisan tanaman terluar memberikan ruang tumbuh yang lebih longgar sekaligus sirkulasi udara dan pemanfaatan sinar matahari lebih baik untuk pertanaman. Selain itu, upaya penanggulangan gulma dan pemupukan dapat dilakukan dengan lebih mudah. Selain itu, juga disampaikan bagaimana proses program dijalankan di lapangan.

Pesan berupa manfaat dan prosedur program dirancang dan disusun untuk dapat menarik perhatian petani dan dapat membangkitkan rasa membutuhkan petani akan teknologi tanam jajar legowo padi. Pesan tersebut juga diikuti dengan bagaimana cara menerapkan teknologi tersebut di lahan petani. Pesan ini disampaikan penyuluh pada saat melakukan kegiatan pelatihan teknis tajarwo, ceramah, diskusi dengan kelompok tani serta demonstrasi atau praktek langsung di lapangan.

$\mathrm{Di}$ dalam sebuah pesan terkandung isi pesan. Isi pesan adalah sebagai materi atau bahan dalam pesan yang telah dipilih oleh sumber untuk mengatakan maksudnya. Menurut Cangara (2014:141) ada dua bentuk teknik 
penyusunan pesan, yakni One side issue (sepihak) dan Two side issue. Dalam hal ini, pesan komunikasi yang disampaikan penyuluh pertanian Koto Tangah kepada khalayak sasaran kegiatan, tergolong kepada penyajian pesan Two side Issue, dimana pesan tersebut disajikan keduanya sekaligus, baik yang positifnya maupun yang negatifnya. Pesan komunikasi tersebut disajikan dengan bentuk perbandingan antara penerapan teknologi dengan sistem tajarwo dan konvensional.

Pesan teknologi sistem tajarwo haruslah mudah dipahami, dan peka terhadap budaya setempat sehingga akan memudahkan dan meyakinkan sasaran bahwa dengan menggunakan teknologi yang baru akan memberikan manfaat yang jelas bagi sasaran. Walaupun, pada kenyataannya belum sepenuhnya dapat mengubah kebiasaan-kebiasaan lama masyarakat, tetapi pesan-pesan yang didapatkan mampu meningkatkan pengetahuan dan pemahaman masyarakat petani akan pentingnya penerapan teknologi sistem tajarwo di lahan mereka masing-masing. Pesan yang disampaikan harus mampu membangun kesadaran bahwa penggunaan teknologi ini tidak sulit dan mudah untuk diaplikasikan serta dapat meningkatkan produksi dan pendapatan petani tanaman padi.

Langkah selanjutnya yang dilakukan oleh penyuluh pertanian kecamatan Koto Tangah adalah menetapkan metode. Metode adalah jalan atau cara yang harus ditempuh untuk mencapai suatu tujuan atau proses untuk menyampaikan informasi. Menetapkan metode berarti memilih suatu cara atau jalan dalam rangka menyampaikan sebuah informasi atau mecapai tujuan komunikasi. Dalam hal ini, tujuan komunikasinya adalah untuk memberikan pengetahuan, pemahaman, kepada khalayak sasaran agar mau berubah ke arah yang diinginkan penyuluh pertanian.

Metode atau cara menjadi penting dalam mengenalkan suatu teknologi yang masih dianggap baru oleh petani. Tanpa adanya metode yang tepat maka tujuan yang akan dicapai tidak akan mudah didapatkan, karena metode berhubungan dengan cara yang dianggap lebih mudah dan bisa diterima oleh masyarakat petani padi. Dalam hal ini, penyuluh pertanian Kota Padang menyampaikan pesan dengan menggunakan metode penyampaian pesan yang dikemukankan oleh Anwar Arifin (1984:77), yakni metode persuasif, metode informatif, metode edukasi, dan metode redudancy (pengulangan).

Menurut Arifin (1984:77), informatif merupakan suatu bentuk penyampaian isi pesan, yang bertujuan mempengaruhi khalayak dengan jalan (metode) memberikan penerangan. Penerangan berarti menyampaikan sesuatu apa adanya, apa sesungguhnya, diatas fakta-fakta dan data-data yang benar serta pendapatpendapat yang benar pula. Metode informatif ditetapkan penyuluh pertanian karena dengan metode ini pesan teknologi yang disebarkan akan cepat sampai kepada masyarakat petani. Bentuk informatif yang ditemukan peneliti di lapangan adalah dalam bentuk penyebaran brosur, leaflet, buku panduan kegiatan kepada para petani di lapangan. Dalam hal ini, penyuluh pertanian menyampaikan pesan komunikasinya dengan memanfaatkan media terutama media cetak.

Persuasif merupakan bentuk penyampaian pesan yang bertujuan untuk mempengaruhi komunikan dengan jalan membujuk. Metode persuasif ditetapkan penyuluh pertanian karena melalui metode ini, penyuluh pertanian berusaha membujuk dan menggugah baik pikiran maupun perasaanya agar mereka terpengaruh sehingga dengan mudah mengikuti apa yang disampaikan penyuluh. Bentuk persuasif yang ditemukan peneliti di lapangan kebanyakan dilakukan oleh penyuluh dalam bentuk lisan. Dalam hal ini penyuluh pertanian berusaha melakukan komunikasi persuasif secara lisan dan personal ketika bertatap muka dengan para petani.

Edukatif, menurut Arifin (1984:77) adalah salah satu cara mempengaruhi khalayak dari suatu pernyataan umum yang dilontarkan. Metode mendidik berarti memberikan sesuatu ide kepada khalayak sesungguhnya, diatas faktafakta, pendapat, atau pengalaman yang dapat dipertanggungjawabkan dari segi kebenarannya, dengan disengaja, teratur dan terencana, dengan tujuan mengubah tingkah laku manusia kearah yang diinginkan. Metode edukatif ditetapkan penyuluh pertanian, karena melalui metode ini diberikan pendidikan dan pelatihan tentang pelaksanaan program teknologi dan prosedur kerjanya di lapangan. Bentuk edukatif yang ditemukan peneliti di lapangan adalah sosialisasi kegiatan, diskusi dan ceramah dalam pertemuan kelompok tani. Dalam metode ini, penyuluh berusaha memberikan pemahaman kepada petani melalui tatap muka agar petani menjadi tahu, paham dan tertarik untuk menerapkan tanam jajar legowo di lahan pertanian mereka.

Kemudian, Redundancy menurut Arifin (1984:77) merupakan cara mempengaruhi khalayak dengan jalan mengulang-ulang pesan kepada khalayak. Dengan metode ini, khalayak akan lebih memperhatikan pesan tersebut dan juga komunikator dapat memperoleh kesempatan untuk memperbaiki kesalahan-kesalahan yang tidak disengaja dalam penyampaian-penyampaian sebelumnya. Metode ini ditetapkan penyuluh karena untuk mempercepat 
pemahaman para petani perlu dilakukan secara berulang. Pesan yang berulang memiliki peluang yang besar untuk bisa dipahami lebih cepat oleh khalayak dan pesan itu akan lebih mudah diingat.

Seleksi dan penggunaan media adalah langkah berikutnya yang digunakan penyuluh pertanian Koto Tangah dalam mengkomunikasikan teknologi sistem tanam jajar legowo kepada petani tanaman padi. Seleksi dan penggunaan media maksudnya adalah kegiatan memilih dan menetapkan media mana yang akan digunakan dalam komunikasi pesan inovasi ini. Pemilihan media tersebut dilakukan tergantung kepada khalayak yang dijadikan sasaran komunikasi kegiatan. Artinya pemilihan media komunikasi harus disesuaikan dengan target sasaran yang akan dituju. Dalam hal ini, penyuluh pertanian memilih dan menggunakan media komunikasi mengacu kepada yang dikemukakan oleh Onong Uchjana Effendy (2011:8-11) bahwa terdapat dua jalan agar pesan dari komunikator sampai ke komunikannya, yaitu tanpa media (nonmediated communication yang berlangsung face-to-face) atau dengan media.

Menurut Onong Uchjana Effendy (2011:811), terdapat dua jalan agar pesan dari komunikator sampai ke komunikannya, yaitu tanpa media (nonmediated communication yang berlangsung face-to-face) atau dengan media. Penyuluh pertanian koto Tangah dalam menyampaikan pesan komunikasinya memanfaatkan keduanya. Penyuluh pertanian menetapkan komunikasi tanpa media atau berlangsung face to face (tatap muka), diantaranya adalah diskusi dan ceramah pada saat melakukan pertemuan kelompok, sosialisasi kegiatan dan sekolah lapang (SL). komunikasi dengan media, yakni media cetak seperti : brosur, leaflet, banner, buku pedoman kerja, spanduk dan media infokus pada saat pelatihan petani. Azizah (2010) dalam penelitiannya mengatakan bahwa rencana strategi untuk media/channel komunikasi adalah: menggunakan media massa (poster, slide, leaflet booklet, majalah) dan komunikasi tatap muka yang bersifat publik (seminar, ceramah). Selanjutnya informasi diberikan melalui media informasi publik yaitu penyuluhan/seminar/ ceramah, demonstrasi/praktek dan buku petunjuk.

Agar lebih jelas, peneliti mencoba mengupasnya yang pertama yang digunakan penyuluh pertanian koto tangah dalam menyampaikan pesannya adalah menggunakan media cetak, yakni buku pedoman, leaflet, dan brosur kegiatan. Kelebihannya media cetak menurut Anggraini (2014) adalah karena dianggap lebih menarik perhatian pelanggan dan praktis dalam penyampaian pesan. Penggunaan media cetak ini dianggap praktis dan bermanfaat untuk memberikan informasi yang bersifat terbuka. Kemudian, media cetak dapat dibaca berulang kali dan mudaht menyimpannya dalam bentuk kliping atau bentuk lainnya. Dalam mengulas berita, media cetak dapat menyajikannya lebih dalam, tajam, serta luas. Hal ini dikarenakan media cetak tidak memiliki pembatasan dalam mencari informasi maupun menyiarkan informasi tersebut.

Media selanjutnya adalah banner dan spanduk, yang dalam hal ini disebut juga dengan media luar ruangan yang ditempatkan di tempattempat rame dilihat oleh orang banyak. Konten yang ada pada spanduk atau banner adalah adanya gambar tentang sistem tanam jajar legowo yang bisa dipadukan dengan tanaman pangan lainnya, kemudian juga dapat terlihat manfaat yang diperoleh jika menerapkan sistem tajarwo padi. sasaran komunikasinya adalah masyarakat umum. Kelebihan menggunakannya adalah bisa tahan lama dan mudah dipindahkan ke tempat lain. Akan tetapi jangkauannya terbatas hanya pada orang yang lewat dan sempat membacanya.

Kemudian, media tatap muka melalui pertemuan dengan kelompok atau kunjungan ke kelompok tani padi. Kunjungan dilakukan agar komunikasi tetap berjalan baik dan lancar. Melaui kunjungan kelompok pesan dapat disampaikan secara lugas dan dapat langsung merespon permasalahan serta segera dicarikan sulusinya. Konten yang disampaikan adalah peninjauan terhadap perkembangan kegiatan di lapangan. Sasaran komunikasi adalah petani penerima manfaat kegiatan. Disitu terjadi komunikasi interpersonal yang intensif dan kelemahannya adalah audiensnya terbatas. Petani dapat langsung terbuka dalam menyampaikan setiap permasalahanya kepada penyuluh pertanian.

Saluran tatap muka selanjutnya adalah pada saat pemberian pelatihan tentang tajarwo kepada petani penerima manfaat kegiatan. Materi atau isi pesan yang diberikan adalah berhubungan dengan cara-cara melaksanakan teknologi sistem tanam jajar legowo, manfaat yang diperoleh dan mengajak pemanfaat kegiatan untuk berpartisipasi aktif dalam menerapkan inovasi ini di lahan pertanian mereka. Penyuluh pertanian menyampaikan materi pesan dengan menggunakan Power Point yang ditayangkan dengan alat infokus. Petani akan lebih mudah memahami pesan karena petani dapat menyaksikan langsung materi berupa gambar yang berwarna dan sangat jelas dengan berbagai variasi. Kelemahannya adalah 
hanya bisa dilihat oleh sebagian orang saja. Disitu juga terjadi diskusi antara petani dengan pemberi materi sehingga setiap permasalahan dapat dipecahkan bersama.

Dari uraian diatas dapat dilihat bahwa belum semua saluran komunikasi dimanfaatkan dengan baik oleh penyuluh pertanian Koto Tangah Kota Padang, sesuai dengan kemudahan akses para pihak. Media massa dan media publik belum dipergunakan secara maksimal sebagai penyampai pesan sistem tajarwo padi, padahal kedua jenis media ini memiliki kemampuan sebagai wahana pendidikan publik di ruang publik. Media cetak berupa surat kabar belum dimanfaatkan, padahal media ini sangat baik disebarluaskan untuk mereka yang bisa membaca dan memiliki waktu senggang yang cukup. Media elektronik berupa televisi dan radio belum dimanfaatkan, padahal media ini memiliki penyebaran yang cukup luas dan hampir disetiap rumah tangga. Media ini bisa menembus ruang dan waktu sehingga informasinya sangat cepat dan serempak. Media internet juga belum dimanfaatkan dengan baik, padahal menurut Purwatiningsih, dkk (2018) pemanfaatan internet oleh penyuluh terbukti meningkatkan kinerja penyuluh. Gumilar (2014) juga mengatakan bahwa bahwa perkembangan Internet sekarang ini berpengaruh terhadap berbagai bidang termasuk untuk menyebarkan informasi dan promosi. Dengan menggunakan saluran komunikasi massa, maka pesan yang disebarkan akan bisa langsung dilihat banyak orang. Media masa biasanya lebih efektif dan lebih murah untuk mengenalkan inovasi pada tahap-tahap penyadaran dan menumbuhkan minat masyarakat.

Menggunakan kombinasi dari berbagai macam saluran akan menambah kemungkinan proses komunikasi dapat berhasil dengan baik. Semakin banyak ragam media yang digunakan oleh pihak-pihak yang berkomunikasi (baik sumber maupun penerima manfaat), maka akan memberikan pengaruh yang sangat baik dalam pencapaian tujuan komunikasi. Karena selain jumlah informasi menjadi lebih lengkap, biasanya juga lebih bermutu/semakin memberikan kejelasan terhadap inovasi yang diterimanya. Menurut Susanti (2015) untuk mencapai sasaran komunikasi yang efektif dapat dipilih salah satu atau gabungan dari beberapa media, tergantung dari tujuan yang akan dicapai, pesan yang akan disampaikan, dan teknik yang digunakan. Masing-masing media mempunyai kelebihan dan kekurangan.

Dengan demikian, strategi komunikasi yang dilakukan dalam kegiatan penerapan teknologi sistim tajarwo haruslah dapat menyesuaikan dengan situasi yang ada di lapangan. Ketika menggunakan media massa sebagai ujung tombak penyebaran informasi ke masyarakat, haruslah dipilih media yang benar-benar dapat diakses langsung dan bisa menyampaikan pesan teknologi kepada masyarakat, misalnya dengan mengotimalkan penyebaran informasi melalui leafleat yang diakui sebagai media yang mudah diakses dengan informasi yang tepat dan mudah dipahami. Penyebaran informasi melalui media massa lain seperti koran, audio, audio visual tetap diperlukan, untuk menyebarkan informasi secara masal dan juga untuk memperkaya informasi bagi "pemuka pendapat" yang lebih mampu mencari dan memanfaatkan informasi dari media.

Setelah merumuskan strategi komunikasi yang digunakan dalam mengenalkan teknologi sistem tanam jajar legowo, maka penyuluh pertanian mengimplementasikan aksi strategi komunikasinya melalui sosialisasi program ke masyarakat dan kebiasaan- kebiasaan masyarakat yang suka berkumpul dan dudukduduk dikedai dalam membicarakan sesuatu.

Sosialisasi program ke masyarakat. Sosialisasi program adalah proses pemberian informasi, pengadaptasian, penyesuaian, pengenalan dan penjabaran program sehingga dapat diketahui oleh masyarakat umum. Sosialisasi merupakan kegiatan awal dari serangkaian proses suatu kegiatan. Khalayak yang dijadikan sasaran komunikasi adalah petani/kelompok tani sebagai pemanfaat program, pemerintahan kelurahan, tokoh masyarakat, dan pelaksana kegiatan. Disini juga diundang pakar yang lebih menguasai kegiatan, baik dari BPTP atau narasumber dari pusat untuk lebih meyakinkan peserta sosialisasi akan pentingnya pelaksanaan program pemerintah. Materi atau isi pesan yang disampaikan penuluh pertanian Koto Tangah adalah manfaat program, prosedur kerja, serta ajakan untuk berkomitmen dan bertanggungjawab dalam mensukseskan program pemerintah. Metode penyampaian pesan yang digunakan adalah metode informatif, persuasif dan edukatif. Untuk mempermudah cepat terserapnya materi sosialisasi, penyuluh pertanian Koto Tangah juga memanfaatkan media infokus melaui tampilan power point, dimana peserta bisa langsung melihat dan menyaksikan tahap-tahap pelaksanaan kegiatan. Dimana, pesan yang disampaikan menjadi sangat jelas, terstruktur dan mudah dipahami karena dilengkapi dengan contoh-contoh dan gambargambar yang menarik. Sehingga dengan ini, bisa menarik minat dan keinginan dari peserta untuk merubah pola pertanian lama ke pola pertanian yang baru, sesuai dengan yang diharapkan penyuluh pertanian. Media yang lain digunakan pada saat sosialisasi adalah media spanduk 
yang di pasang di persimpangan jalan dan media banner yang dipasang dekat dengan tempat sosialisasi.

Dalam mengimplementasikan strategi komunikasi kepada masyarakat petani, kebiasaan masyarakat petani seperti suka berkumpul dan duduk-duduk di kedai, di lahan atau bahasa lainnya adalah "kebiasan maota sabalun bekerja" dapat dimanfaatkan oleh penyuluh pertanian untuk mengenalkan sesuatu yang dianggap baru oleh petani seperti teknologi sistem tanam jajar legowo tanaman padi. Diskusi-diskusi informal tersebut, lebih disukai petani dari pada diskusi fiormal, karena dalam diskusi informal sifatnya lebih santai, menggunakan bahasa daerah yang membuat mereka nyambung dalam berdiskusi, suasananya lebih akrab dan bisa memungkinkan terjadi diskusi terbuka diantara mereka. Disinilah peran seorang penyuluh dituntut untuk dapat dekat dengan petani, membaur dan merasa dibutuhkan kehadirannya di tengah-tengah para petani. Penyuluh harus bisa sebagai motivator, mediator, fasilitator dan komunikator yang handal dalam menjawab setiap permasalahan petani. Untuk mewujudkan hal tersebut, penyuluh harus melakukan pendekatan-pendekatan kepada masyarakat petani, seperti : pendekatan terarah, kelompok dan pendekatan pendampingan. Menurut Zamzami (2012) ada 3 pendekatan yang dilakukan kepada masyarakat yakni (1) pendekatan yang terarah, dimana pemberdayaan masyarakat harus terarah dan berpihak kepada kelompok masyarakat miskin. (2), pendekatan kelompok, dimana secara bersama-sama masyarakat berusaha memecahkan masalah yang dihadapi. (3), pendekatan pendampingan, dimana dalam proses pembentukan dan penye lenggaraan kelompok masyarakat miskin perlu didampingi oleh pendamping yang profesional sebagai fasilitator, komunikator, dan dinamisator terhadap kelompok untuk mempercepat tercapainya kemandirian.

\section{KESIMPULAN}

D ari hasil penelitian, disimpulkan bahwa strategi komunikasi yang digunakan penyuluh pertanian dalam mengkomunikasikan teknologi sistem tanam jajar legowo (tajarwo) kepada petani padi di Kecamatan Koto Tangah Kota Padang adalah: mengenal khalayak, menyusun pesan komunikasi, menetapkan metode, dan memilih media komunikasi. Pertama, Dalam mengenal khalayak, penyuluh pertanian Kota Padang mengacu kepada aspek sosiodemografik, diantaranya dilihat dari sisi pekerjaan dan tingkat pendapatan. Kedua, menyusun pesan. Penyuluh menyusun pesan komunikasinya berdasarkan kepada kebutuhan, keinginan, sikap, tingkah laku dan pengetahuan khalayak, sosial budaya, dan tingkat pemahaman masing-masing khalayak sasaran. Pesan yang disampaikan kepada khalayak adalah manfaat program dan prosedur pelaksanaan program di lapangan. Ketiga menetapkan metode, dalam menyampaikan pesan penyuluh pertanian menggunakan metode persuasif, informatif, edukatif dan dilakukan secara berulang-ulang. Keempat, seleksi serta penggunaan media komunikasi. Media komunikasi yang dipilih dan digunakan dalam menyampaikan pesan adalah tanpa media atau tatap muka, berupa diskusi dan ceramah dalam pertemuan kelompok tani, dan dengan media berupa brosur, leaflet, banner, spanduk, dan media elektronik berupa infokus pada saat memberikan materi pesan komunikasi. Selain itu, dalam mengenalkan teknologi jajar legowo penyuluh pertanian bisa memenfaatkan kebiasaan-kebiasaan masyarakat seperti suka berkumpul dan duduk di kedai, di lahan mereka atau dengan kata lain adalah tatap muka langsung dengan masyarakat petani.

Dalam penelitian ini, disarankan kepada penyuluh pertanian untuk meningkatkan kapabilitas dan kreativitasnya dalam menyusun strategi komunikasi yang efektif, agar terlihat menarik, gampang diingat dan tidak membosankan. Kemudian, media komunikasi lebih baik menggunakan gabungan beberapa media antara media cetak, media elektronik dan media internet dalam menyampaikan pesan komunikasinya. Karena menggunakan kombinasi dari berbagai macam saluran akan menambah kemungkinan proses komunikasi dapat berhasil dengan baik, dan dapat dengan mudah dimengerti oleh sasaran.

\section{E. UCAPAN TERIMA KASIH}

T erima kasih penulis ucapkan kepada Badan Kepegawaian Daerah (BKD) dan Badan Pengembangan Sumber Daya Manusia (BPSDM) Provinsi Sumatera Barat yang telah memberikan bantuan dana untuk kelancaran pembuatan artikel ini dan kepada FISIP Universitas Andalas yang telah memberikan fasilitas untuk terbitnya artikel 


\section{DAFTAR PUSTAKA}

Arifin, A. (1984). Strategi komunikasi: sebuah pengantar ringkas. Bandung: Armico.

Anggraeni, N., Siswoyo, M., dan Nurfalah, F. (2014). Strategi Public Relations Dalam Mendukung Pemasaran Pembangkit Listrik Nasional (PLN). Jurnal ASPIKOM, 2 (3), 206-220.

Azizah, S. (2010). Strategi Komunikasi Pembinaan Pembudidayaan Kambing Boer untuk Meningkatkan Taraf Ekonomi Masyarakat di Desa Wonosari, Kecamatan Wonosari, Kabupaten Malang, Provinsi Jawa Timur. Jurnal Ilmu Komunikasi, 7 (1), 100-128.

Cangara, H. (2014). Pengantar IImu Komunikasi. Edisi Revisi. Jakarta: PT. RajaGrafindo Persada.

Effendy, O.U. (2011). Komunikasi Teori dan Praktek. Bandung: PT. Remaja Rosdakarya.

Farid, A., Romadi, U., Witono, D. (2018). Faktor-Faktor yang Mempengaruhi Adopsi Petani dalam Penerapan Sistem Tanam Jajar Legowo di Desa Sukosari Kecamatan Kasembon Kabupaten Malang Provinsi Jawa Timur. Jurnal Penyuluhan, 14 (1), 112-125.

Fatchiya, A., Amanah, S., Kusumastuti, Y.I. (2016). Penerapan Inovasi Teknologi Pertanian dan Hubungannya dengan Ketahanan Pangan Rumah Tangga Petani. Jurnal Penyuluhan, 12(2), 190-197.

Firdaus. (2015). Sistim Tanam jajar legowo 2 : 1. Aceh : BPPT Balitbangtan Aceh. (online) http://nad.litbang.pertanian.go.id/ind/index.php/info-teknologi /620-sistem-tanam-jajar-legowo2-1. akses tanggal 7 desember 2017.

Fitriani, L. (2013). Analisis Mengkaji Program Padi Tanam Sebatang (PTS) dari kaca mata Teori Difusi Inovasi. Jurnal Ilmiah Dakwah dan Komunikasi, IV (8), 26 - 54.

Gumilar, G. \& Zulfan, I. (2014). Penggunaan media massa dan internet sebagai sarana penyampaian informasi dan promosi oleh pengelola industri kecil dan menengah di Bandung. Jurnal Kajian Komunikasi, 2 (1).

Hidayat, D., Kuswarno, E., Zubair, F., \& Hafiar, H. (2017). Message platform atribut siger lampung di dalam kebhinekaan multikultur. Jurnal Kajian Komunikasi, 5(1), 91-101.

Indardi. (2016). Pengembangan Model Komunikasi Dalam Pemberdayaan Masyarakat Tani. Jurnal Agraris, 2 (1), 75-86.

Kataren, A., Pangeran P.P., \& Nasution, A. (2018). Konflik GAM-RI dan kerentanan pangan masyarakat transmigran. Jurnal Antropologi: Isu-Isu Sosial Budaya, 20(1), 103-117.

Moleong, L. J., (2016), Metodologi Penelitian Kualitatif. Edisi Revisi, Bandung: PT.Remaja Rosdakarya.

Purwatiningsih, Anggoro, N., Fatchiya, F., Mulyandari, R.S.H. (2018). Pemanfaatan Internet dalam Meningkatkan Kinerja Penyuluh Pertanian di Kabupaten Cianjur. Jurnal Penyuluhan, 14 (1), 79-91.

Sugiyono, (2016). Metode Penelitian Kuantitatif, Kualitatif, Dan R\&D. Bandung: Alfabeta.

Susanti, H.A. (2015). Strategi Komunikasi Badan Kependudukan Dan Keluarga Berencana Nasional (BKKBN). Jurnal Komunikasi ASPIKOM, 2(4), 243-254.

Umniyati, N., Hadisiwi, P., \& Suminar, J. R. (2017). Pengaruh terpaan informasi riset melalui website www.ppet.lipi.go.id terhadap sikap mahasiswa mengenai penelitian. Jurnal Kajian Komunikasi, 5(1), 111-120.

Zaini, Z. (2015). Pedoman Umum PTT Padi Sawah. Bogor: Pusat Penelitian dan Pengembangan Tanaman Pangan.

Zamzami, L. (2012). Peranan Lembaga Pengembangan Pesisir Mikro "Mitra Mina" dalam Upaya Pemberdayaan Ekonomi Masyarakat Pesisir di Sumatera Barat. Asian Journal of Innovation and Entrepreneurship, 1(2), 121-128.

Zulkarnain M. Y, Subejo dan Hartono, S. (2017). Strategi Komunikasi dalam Membangun Kebiasaan Makan Pangan Lokal Percepatan Penganekaragaman dan Konsumsi Pangan di Kabupaten Bengkulu Utara. Jurnal IImu Komunikasi, 15(2), 177-188. 